\title{
主機関負荷に与える船体曲げ応力の影響
}

\section{Influence of Longitudinal Bending Stress on the Main Engine Load}

井関 俊夫*・石塚 正則 ${ }^{* *}$ ・大津 皓平 *

\author{
Toshio ISEKI, Masanori ISHIZUKA and Kohei OHTSU
}

\begin{abstract}
It is the purpose of this paper to clarify the influence of longitudinal bending stress on a fluctuation of main engine load. We adopted a stochastic approach using a Multi-variate Auto Regressive (MAR) model in order to analyze vector time series which were obtained in the several on board experiments. And, we derived relative power contributions, impulse response functions and frequency response functions for the stress-engine system from the fitted MAR coefficient matrix.

The results of these analysis are as follows. The relative power contribution of the longitudinal bending stress to a power spectrum of a fluctuation of main engine load takes maximum value in quartering seas. And, a strong correlation is observed between them in case that the stress was based on ship motions. Furthermore, according to the result of impulse response functions, the main engine load increases in hogging condition but decreases in sagging condition.

In this paper, we describe the outline of these analysis, and discuss a few points about the mechanism of that phenomenon.
\end{abstract}

\section{1. 緒 言}

船舶の主機関に加わる負荷は、周囲の波浪の影響と、その結果として起こる船体運動の影響とを受けて 常に変動している。一方、船体は波浪中で運動することにより、変動する縦曲げモーメント等の波浪荷重 の影響を受け、いわゆるホギング，サギングの状態を繰り返す。したがって、主機関の負荷変動と波浪荷 重の変動は大部分において共通する要因によって発生しており、強い相関を持っあのと考えられる。これ らの相関が明らかにされれば、船舶の荒天運航に対する新しい安全指針を得ることが可能であると思われ る。すなわち主機関の負荷の状態は常に監視することが可能であるから、主機関の負荷変動から船体の受 けている波浪荷重を推定できれば、過大な波浪荷重によって船体あるいは貨物に損傷を受けるような事態 を回避することが可能となるからである。荒天中における船舶の運航が現在においても操船者の経験と勘 によって行われていることを考えると、科学的に裏付けられた客観的な安全運航指針が与えられることは 非常に有効であると考えられる。さらにこの考え方を進めると、主機関の負荷変動と波浪荷重の变動との 相関を明らかにすることは、主機関と船体強度とを同時に監視するシステムの研究開発や新しい電子ガバ ナシステムの開発(1) 等に対しであ十分役立つあのと考えられる。しかしながら、主機関の負荷变動に関す る研究と波浪荷重に関する研究はそれぞれ異なった分野に属するために、これらの相関を取り上げた研究 は著者らの知る限りほとんどないようである。

本研究では、波浪荷重が主機関の負荷変動に与える影響を明らかにすることを目的として、東京商船大

* 正会員 東京商船大学 (T135 東京都江東区越中島 2-1-6)

** 正会員 東京商船大学研究生 (下135 東京都江東区越中島 2-1-6) 
学附属練習船汐路丸を用いて実船データを収集した。さらにその結果をもとに多次元自己回帰モデルによ るクロススペクトラム解析(2)を行い、主機関の負荷変動ならびに船体縦曲げ応力の変動に対して雑音寄与 率(3) の解析を行うことを試みた。得られた結果を検討することによって若干の知見を得たので、その結果 について報告する。

\section{2. 解析方法}

\section{1 インパルス応答}

解析の対象となる $k$ 種類の時系列 $x_{i}(s), i=1, \ldots, k$ が観測され、それぞれの時系列が次に示すよう な多次元線形フィードバックシステムで表されると仮定する。

$$
x_{i}(s)=\sum_{j=1}^{k} \sum_{m=1}^{M} h_{i j}(m) x_{j}(s-m)+u_{i}(s), \quad i=1,2, \cdots, k
$$

ここで、 $h_{i j}(m)$ は $x_{j}(s)$ から $x_{i}(s)$ へのインパルス応答関数で、 $h_{i i}(m)=0$ とする。また $M$ はモデルの次 数であり、 $u_{i}(s)$ は $i$ 番目のループに入り込む有色ノイズであるとする。

このモデルにおいて、有色ノイズ $u_{i}(s)$ を次のような $L$ 次の自己回帰モデルで表すことによりノィズの 白色化を行う。

$$
u_{i}(s)=\sum_{l=1}^{L} c_{i}(l) u_{i}(s-l)+\varepsilon_{i}(s)
$$

ただし、 $\varepsilon_{i}(s)$ は白色ノィズである。ここで、 $u_{i}(s)$ を消去するために(1)式を次のように変形し、

$$
u_{i}(s)=x_{i}(s)-\sum_{j=1}^{k} \sum_{m=1}^{M} h_{i j}(m) x_{j}(s-m)
$$

この式を(2)式に代入して整理すれば、以下に示す $k$ 次元自己回帰モデルに変換することができる。

$$
X(s)=\sum_{m=1}^{M} A(m) X(s-m)+W(s)
$$

ただし、

$$
\begin{aligned}
& X(s)=\left(\begin{array}{c}
x_{1}(s) \\
x_{2}(s) \\
\vdots \\
x_{k}(s)
\end{array}\right), W(s)=\left(\begin{array}{c}
\varepsilon_{1}(s) \\
\varepsilon_{2}(s) \\
\vdots \\
\varepsilon_{k}(s)
\end{array}\right) \\
& A(m)=\left(\begin{array}{cccc}
A_{11}(m) & A_{12}(m) & \cdots & A_{1 k}(m) \\
A_{21}(m) & A_{22}(m) & \cdots & A_{2 k}(m) \\
\vdots & \vdots & \ddots & \vdots \\
A_{k 1}(m) & A_{k 2}(m) & \cdots & A_{k k}(m)
\end{array}\right)
\end{aligned}
$$

である。また、(1)式のインパルス応答関数 $h_{i j}(m)$ と自己回帰係数行列 $A_{i j}(m)$ との関係は、

で与えられる。

$$
\left.\begin{array}{l}
h_{i j}(1)=A_{i j}(1) \\
h_{i j}(m)=A_{i j}(m)+\sum_{l=1}^{m-1} A_{i j}(l) h_{i j}(m-l)
\end{array}\right\}
$$

したがって、観測された時系列 $x_{i}(s), i=1, \ldots, k$ から最小自乗法を用いて自己回帰係数行列 $A(m)$ を 決定すれば、(5)式からインパルス応答関数を求めることができる。なお、モデルの次数 $M$ は MAICE 法 ${ }^{(2)}$ によって決定できる。

\section{2 パワースペクトラムと雑音寄与率}

多次元自己回帰モデル (4) 式のフーリエ変換をとり、 $B(f)=(I-A(f))^{-1}$ とおくと (4) 式は、

$$
X(f)=B(f) \cdot W(f)
$$

と表される。 $X(s)$ のパワースペクトラム $S_{x x}(f)$ は、

$$
S_{x x}(f)=E\left[X(f) \cdot X^{* T}(f)\right]
$$

で与えられるので、 $S_{x x}(f)$ の対角項 $s_{i i}(f)$ に注目する之、 


$$
\begin{aligned}
s_{i i}(f) & =E\left[\sum_{j=1}^{k}\left|b_{i j}(f)\right|{ }^{2} \varepsilon_{i}^{2}(f)\right] \\
& +E\left[\sum_{j 1=1}^{k} \sum_{j 2=1}^{k} b_{i j 1}(f) b_{i j 2}(f)^{*} \varepsilon_{j 1}(f) \varepsilon_{j 2}^{*}(f)\right]
\end{aligned}
$$

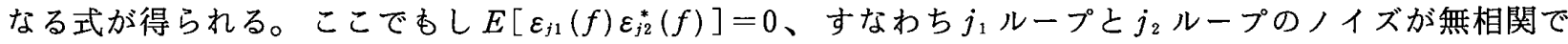
あるならば、上式の右辺第 2 項はゼロとなり、結局 $x_{i}(s)$ のオートスペクトラム $s_{i i}(f)$ は

$$
s_{i i}(f)=\sum_{j=1}^{k}\left|b_{i j}(f)\right|{ }^{2} s_{e j}^{2}(f)
$$

のように $\varepsilon_{j}(s)$ のスペクトムの和によって表現されることが分かる。この式を用いて雑音寄与率

$$
\gamma_{i j}(f)=\frac{\left|b_{i j}(f)\right|^{2} s_{e j}(f)}{s_{i i}(f)}
$$

を定義することができる。

\section{3. 結果および考察}

\section{1 実船実験データの概要}

解析に用いた実験データは平成 4 年 3 月から平成 5 年 7 月までに行われた実験航海ならびに学生実習航 海において計測されたものであり、館山湾から伊豆大島にかけての海域に扣いて船速 12 ノットから14 ノットで直進しているときのデータを選び出したあのである。計測項目は針路, 船首上下加速度, 縌摇れ, 横摇れ, 波高, 船体 2 力所における縦曲げ応力, 主機回転数, 主機負荷指針および舵角の計 10 項目とし た。歪ゲージは汐路丸の船体の 4 力所に貼付してあり、その中で計測に用いたものは船体中央部の船底外 板ならびに船楼甲板に貼付されたすのを選んだ。また、波高データは本船船首部に搭載されたマイクロ波 式波高計によって得られたものであり、主機負荷指針は然料ポンプラック位置の変動量 $(\mathrm{mm})$ を計測し たものである。これらのデータは本船の研究データ収集システム上のラインコンピュータによってサンプ リングされ、内蔵のハードディスクに記録される。なお、データのサンプリング周期は 0.5 秒とした。

3.2 雑音寄与率の解析手順ならびに解析結果

2.で述べたように、雑音寄与率を求める場合に は、寄与する複数の雑音がそれぞれ無相関である必 要があるので、実際の解析では図 1 に示すように 3 段階に分けて解析を行った。すなわち、まず第 1 段 階として船体曲げ応力が主機関の負荷変動に与える 影響を調べるために、船体曲げ応力単独の雑音寄与 率を計算した。次に船体曲げ応力のパワースペクト ラムがどのような雑音の影響を受けているかを調べ るために、船体運動と波高の雑音寄与率をそれぞれ 分けて計算した。したがって、第 2 段階として船体 運動から船体曲げ応力への雑音寄与率を計算し、第 3 段階として波高から船体曲げ応力への単独の雑音

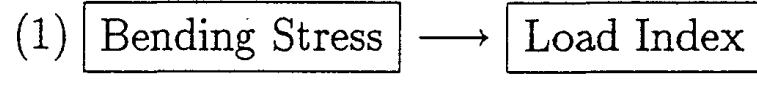

(2)

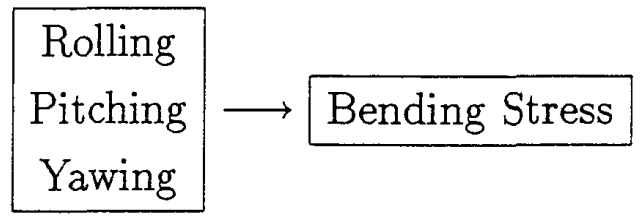

(3)

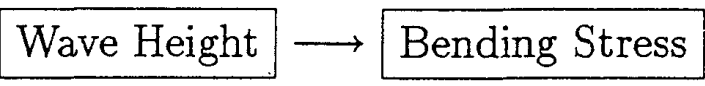
寄与率を計算した。なお、船体運動データは比較的相関の低いと考えられる横摇れ，縦摇れおよび船首摇 れの 3 つを選んだ。

図 2 ならびに図 3 は、船体と波との出会い角に対する雑音寄与率の変化を示すグラフである。グラフの 中の丸印は 1 回の計測で得られた時系列データを解析した結果であり、グラフ中の曲線は丸印のデータ点 に対してフーリエ cosine 級数の 3 次の項までをとった曲線である。また、船体と波との出会い角は、追い 波状態を 0 度とし、正面向かい波状態を 180 度と定義している。これらの 2 つ図のなかで、図 2 は船体 曲げ応力から主機負荷変動への雑音寄与率の変化を表示しており、雑音寄与率は横波状態と追い波状態で 低く、正面向かい波状態と斜め追い波状態で大きくなる傾向があることを示している。図 3 はその逆の主 機負荷変動から船体曲げ応力への雑音寄与率の変化を表示して抢り、雑音寄与率は全ての出会い角に対し て低いことが示されている。これらの図から船体曲げ応力の変動と主機負荷变動の関係は一方向的な関係 
であることがわかる。

波との出会い角に対する船 体曲げ応力からの雑音寄与率 の変化 (図 2 ) を詳しく見る ために、図 4 (a) から図 4 (d) に斜め向汃波, 横波, 斜め 追い波，追い波の 4 つの状態 における主機負荷変動のパ ワースペクトラムを示す。こ こでは 4 つの状態における海 象条件をできるだけ等しくす るために、船載式波高計デー タから計算される有義波高が $0.9 \mathrm{~m}$ から $1 \mathrm{~m}$ となるデー夕 を選んで比較している。なお これらの図において、船体曲 げ応力からのスペクトラムの 寄与分は疎なハッチングで表 されており、主機負荷変動自 身の雑音の寄与分は密なハッ チングで表されている。また、 それぞれの雑音の囲む面積が 全体のパワースペクラムの囲 む面積に占める割合をパーセ ンテージで図中に示している。 向加い波状態加ら追い波状態 になるにしたがってピーク周 波数が低周波側へ移動すると ともに、斜め追い波状態で船 体曲げ応力からの寄与率が最 大となる様子が良くわかる。

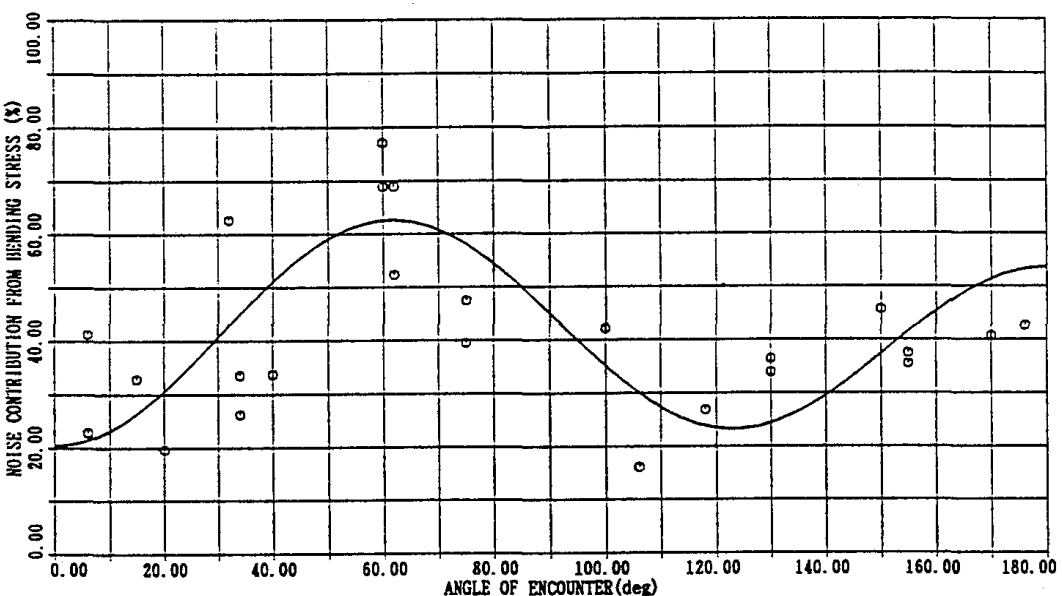

図 2 船楼甲板曲げ応力変動から主機負荷変動 への雑音寄与率

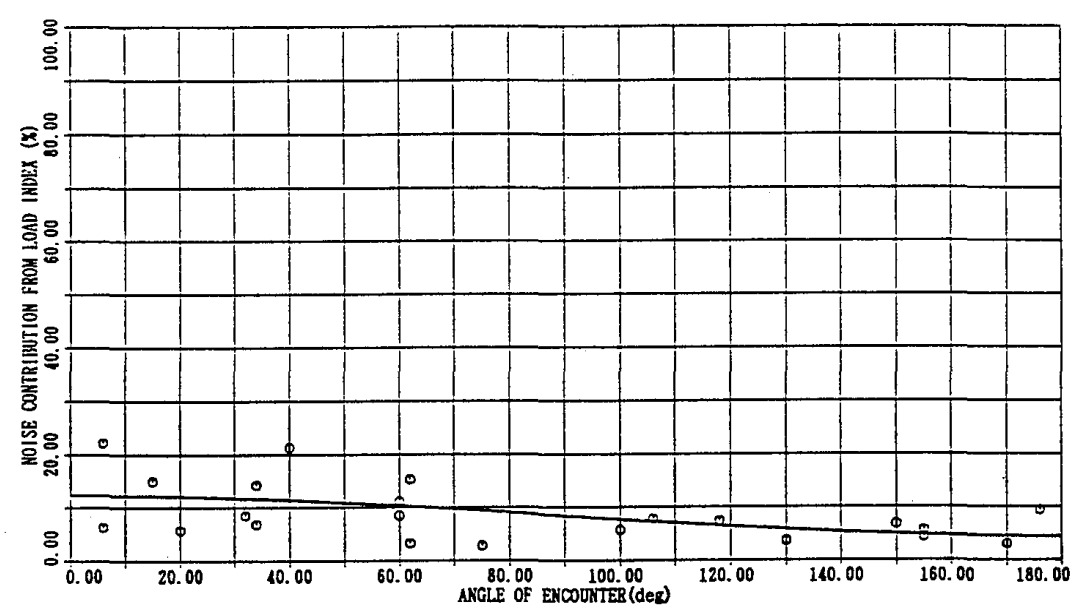

図 3 主機負荷変動から船楼甲板曲げ応力変動 への雑音寄与率

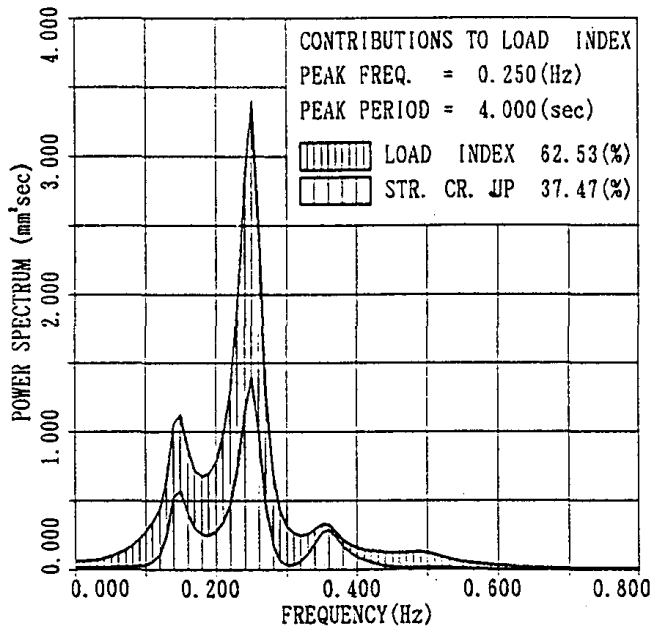

図 4 (a) 主機負荷変動のパワースペクトラム 斜め向かい波状態(出会い角 155 度)

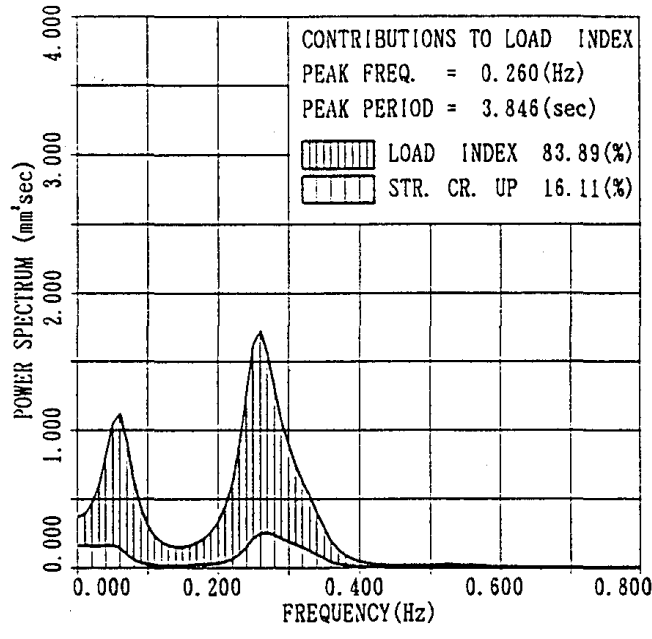

図 4(b) 主機負荷変動のパワースペクトラム 横波状態 (出会い角 106 度) 


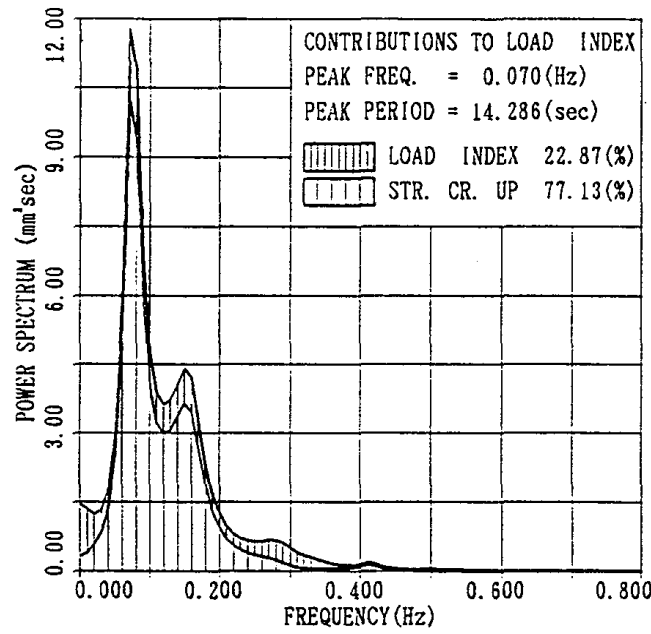

図 4 (c) 主機負荷変動のパワースペクトラム 斜め追い波状態 (出会い角 60 度)

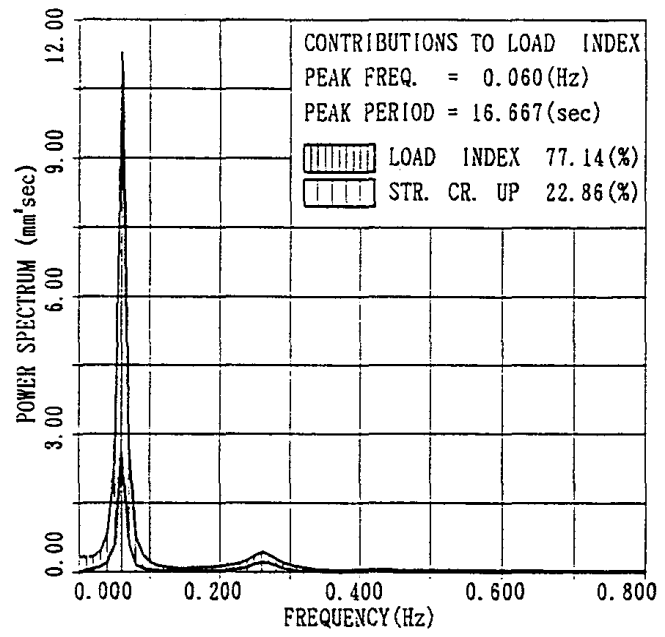

図 4 (d) 主機負荷変動のパワースペクトラム 追い波状態 (出会い角 6 度)

次に、図 4 に示した状態における船体曲げ枕力が船体運動ならびに波高からどのように影響を受けてい るかを見るために、図 5 (a)ならびに図 5 (b) に船体曲げ応力変動のパワースペクトラムの一例を示す。こ れらの図は斜め向かい波状態における結果であり、図 4 (a) と同じ実験デー夕から得られたあのである。図 5 (a) と図 5 (b) は同一の結果であるが、図 $5(\mathrm{a})$ が横摇れ，緹摇れ，船首摇れの 3 つの船体運動からの雑音寄 与率を示しているのに対し、図 5 (b) は波高からの雑音寄与率を示しているところが異なる。これらの図を

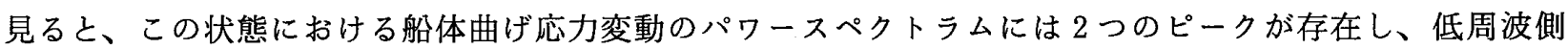
のピークのほとんどは船体運動の寄与によって成り立っており、高周波側のピークのほとんどは波高の寄 与によって成り立っていることがわかる。すなわち、低周波側のピークは船体運動を伴う船体縦曲げモー メントに基づくものであり、高周波側のピークは船体運動を伴わない船体のホギング・サギングモーメン トに基づくものであるといえる。参考までに高周波側のピーク周波数を出会い周波数とする波の波長を計 算すると $39.8 \mathrm{~m}$ となり、汐路丸の垂線間長 $46.0 \mathrm{~m}$ の波方向の cosine 成分 $41.7 \mathrm{~m}$ に非常に近い值となって いることがわかる。さらに、これらの図と図 $4(\mathrm{a})$ とを比較すると、高周波側のピークに対応するピークは 主機負荷変動のパワースペクトラムには現れていないことがわかる。したがって、船体運動に基づく船体 曲げ応力が主機負荷変動に影響を与えているといえる。

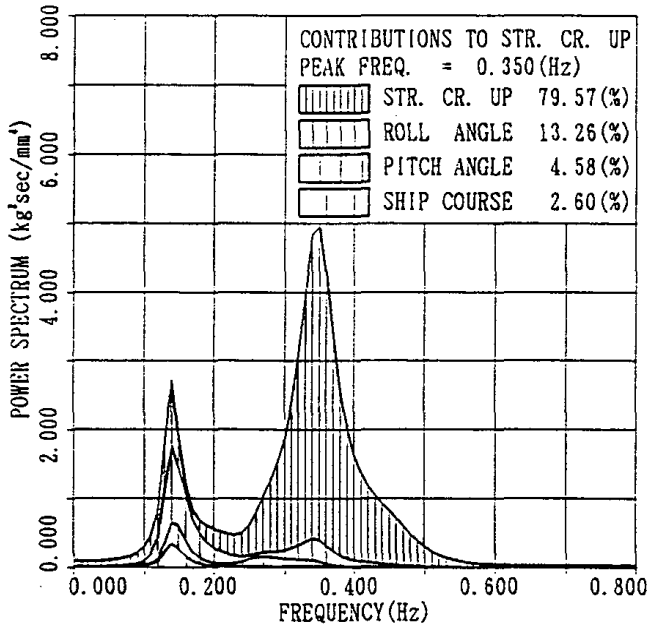

図 5 (a) 船楼甲板曲げ応力変動のパワースペクト ラム

船体運動加らの寄与 (出会い角 155 度)

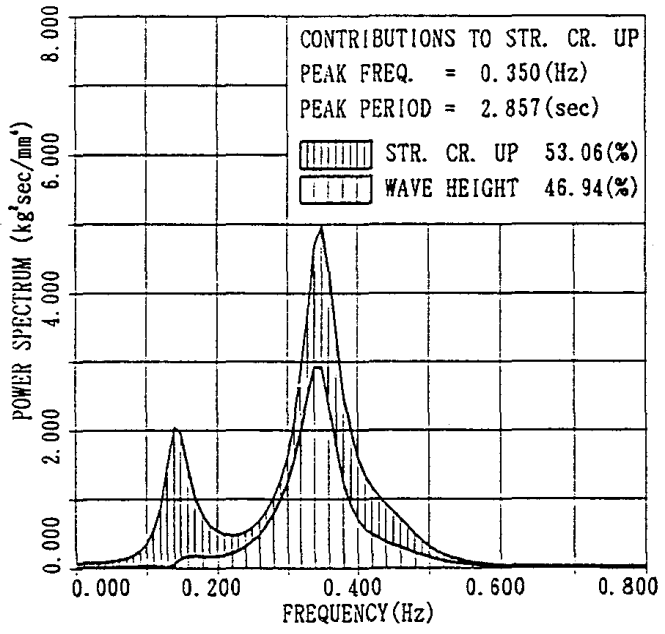

図 5 (b) 船楼甲板曲げ応力変動のパワースペクト ラム

波高からの寄与 (出会い角 155 度) 
図 6 (a) と図 6 (b) にインパルス応答を求めた結果の一例を示す。これらの図は斜め追い波状態における 結果であり、図 4 (c) と同じ実験データから得られたものである。図 $6(\mathrm{a})$ と図 6 (b) はともに船体曲げ応力 から主機負荷变動へのインパルス応答であるが、図6(a)が船体中央部船楼甲板に貼付された歪ゲージから のデータを用いて計算したのに対し、図 6 (b) は船体中央部船底外板に貼付された歪ゲージからのデー夕を 用いて計算しているところが異なる。どちらの歪ゲージのデータも圧縮を正として計測しているので、こ れらの結果より主機関の負荷はサギングのインパルスに対しては軽くなる応答を示し、ホギングのインパ ルスに対しては重くなる応答を示していことがわかる。この現象は追い波状態における波の流体粒子の運 動方向之船体の進行方向との関係から理解することができる。すなわち、サギング状態において船体は波 の谷に位置することになるが、そのときの orbital motion に基づく流体粒子の運動方向は船体の進行方向 とは逆向きであり、プロペラ流入速度を增加させる方向であるために主機関の負荷は軽減されると考えら れる。これとは逆のホギングの状態においては、船体は波の山に位置していると考えられ、そのときの流 体粒子の運動方向は船体の進行方向と同じであることから、プロペラ流入速度を減少させ、結果として主 機関の負荷を増大させるものと考えられる。

図 7 に斜め向かい波，横波，斜め追い波，追い波の 4 つの状態に抢ける船体曲げ応力から主機負荷変動 への周波数応答関数を示す。計算に用いたデータは図 4 の計算で用いたものと同じものである。これらの 結果のみから知見を得ることは困難であるが、ただ一つ注目されることとして次のことが言えると思われ る。すなわち、波との出会い角によって応答振幅のピーク周波数は变化するが、最大值はほぼ一定であり、 その值は約 $1.2\left(\mathrm{~mm}^{3} / \mathrm{kg}\right)$ であることである。この応答振幅の值を実際の值に換算して考えるならば、船 体中央部船楼甲板における縦曲げ応力 $1\left(\mathrm{~kg} / \mathrm{mm}^{2}\right)$ に対して主機関の馬力変動が約 $60 \mathrm{PS}$ であることを意 味する。この馬力は汐路丸の航海速力 14 ノットに対する出力 $1,200 \mathrm{PS}$ の $5 \%$ に相当する。

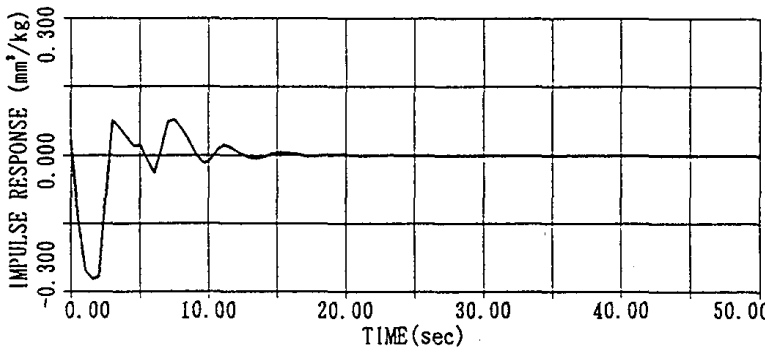

図 6 (a) 船楼甲板曲げ応力変動から主機負荷変動 ヘのインパルス応答 (出会い角 60 度)

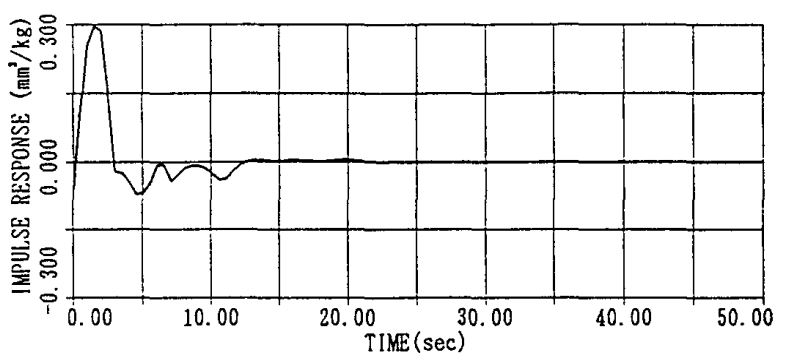

図 6(b) 船底外板曲げ応力変動からの主機負荷変動 へのインパルス応答 (出会い角 60 度)
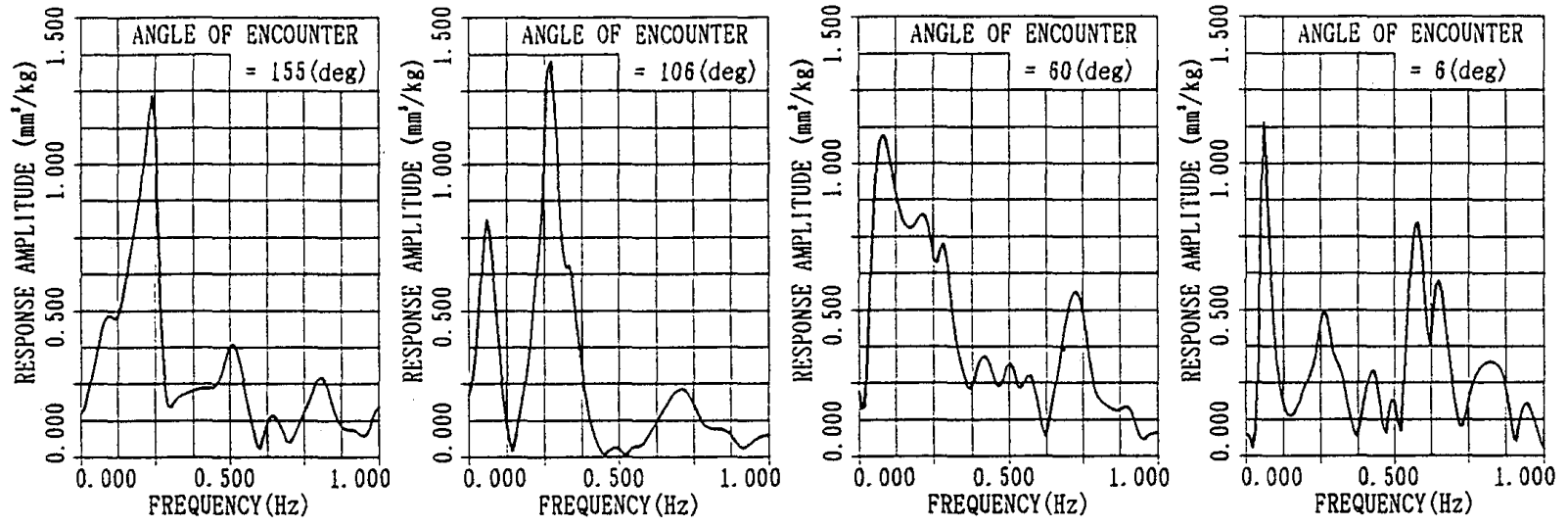

図 7 船楼甲板曲げ応力変動から主機負荷変動への周波数応答 


\section{4. 結 言}

本報告では、実船実験によって得られたデー夕をあとに、多次元自己回帰モデルを用いた解析法により 雑音寄与率、インパルス応答関数ならびに周波数応答関数を求め、船体縦曲げ応力が主機関の負荷変動に 与える影響を調べた。得られた結果をまとめると次のようになる。

1. 船体曲げ応力から主機負荷変動への寄与は斜め追い波状態で最大となる。

2. 主機負荷変動から船体曲げ応力への寄与は波との出会い角に関係なくほとんど無い。

3. 船体運動によって生ずる船体曲げ応力の変動は、主機関の負荷変動に大きく寄与する。

4. 船体曲げ応力に対する主機関負荷変動の応答振幅は、波との出会い角によってピーク周波数は変化 するあのの、その最大值はほぼ一定であり約 $1.2\left(\mathrm{~mm}^{3} / \mathrm{kg}\right)$ であった。

上述の結果の中には、本実船実験の供試船特有のあのああると思われるが、各種船型についてこの種の デー夕を蓄積して行けば荒天中における運航指針に関する情報を導き出せるのではないかと考元られる。 またそのためには、船体曲げ応力が主機関の負荷変動に影響を与えるメカニズムを理論的に解明すること が今後の課題であると思われる。

\section{5. 謝 辞}

本研究の発案ならびに遂行に際して、東京商船大学附属練習船汐路丸堀田敏行機関長には貴重なる助言 とご討論を睗りました。また実船実験に際しては、汐路丸歴代船長をはじめ乗組員の方々にはいつむ快い ご協力を頂きました。心から感謝の意を表します。さらに、本論文の作成に当たりご協力下さいました織 田美千子さんに厚く御礼申し上げます。最後に、本研究は東京商船大学百周年記念事業奨学寄付金抒よび 教育研究学内特別経費の援助を得て行われたものであることを付記し、併せて関係各位に御礼申し上げま す。

\section{参 考 文 献}

（1）石塚正則，他：主機関の統計的同定と最適制御に関する研究（第 1 報），(第 2 報)，日本造船学会論 文集, 第 170 号 (1991)，第 171 号 (1992)

（2）大津皓平，他：保釬運動の統計的同定と最適制御，日本造船学会論文集，第 139 号，(1976)

(3) 赤池弘次, 他：ダイナミックシステムの統計的解析と制御，サイエンス社， (1972) 